\title{
Earthquake Performance Analysis of Existing Reinforced Concrete Structure in the Istanbul Metropolitan Area Using Non-Linear Method
}

\author{
Özlem Çavdar \\ Gumushane University \\ Department of Civil \\ Engineering \\ Gümüşhane, Turkey
}

\begin{abstract}
Many people suffer loss of life and property due to the earthquake disaster in Turkey. In order to minimize this disaster, the resistance of the structures to earthquake should be determined under the light of studies done before. Turkey is in one of the most dangerous seismic regions in the World. As a sub plate between the large Eurasian, Arabian and African plates, Turkey rests on the Anatolian tectonic plate. Arabian plate in the direction of pushing Turkey to the North, the Anatolian plate moves in the opposite clockwise. However, it is prevented to move in the North direction due to the Eurasian plate. In this case, it contains many active faults and Turkey's most populous city of Istanbul is in danger. In this study, it is aimed to perform a performance analysis according to the Turkey Building Earthquake Code 2018 in a six-story reinforced concrete shear wall-framed structure in Istanbul where active fault lines are located. This existing complex designed reinforced concrete building investigated in this study is in the city of İstanbul, Turkey. This city is under danger of approaching and inevitable Great Istanbul Earthquake likely greater than Mw 7. The nonlinear seismic behavior of a complex reinforced concrete (RC) residential building is investigated by and linear and the static pushover. The selected reinforced concrete structure was designed according to 1998 version of Turkish Earthquake Code (TEC-1998). In the earthquake engineering, performance-based design method is used to determine the level of expected performance of the structures under the earthquake effect. According to the code, the reinforced concrete shear wall building is not expected to satisfy controlled damage (life safety) performance levels under design earthquake

Keywords: Reinforced concrete shear-wall structure; failure analysis, performance-based design; Turkey Building Earthquake Code 2018.
\end{abstract}

\section{INTRODUCTION}

A large part of the territory of Turkey is facing earthquake hazards. Earthquake researches have been carried out in Turkey where earthquakes have caused loss of life and property in a very short time and as a result many earthquake regulations have come into force. Istanbul districts close to the Marmara Sea are at higher risk of earthquakes. Turkey's most populated city saw changes in terms of risk after an update of an earthquake risk map dating back to 1996. In the early hours of August 17, 1999, a 7.4 magnitude earthquake rattled the Marmara region east of Istanbul for 45 seconds. More than 18.000 people were killed, according to official numbers, with another 50.000 injured and nearly 300.000 left homeless. The Izmit earthquake and another deadly, quake three months later in the city of Duzce that killed nearly 900 people highlighted the loose construction standards across Turkey and the ill preparedness of emergency services. The Marmara Sea region housing one third of Turkey population is one of the most tectonically active regions in Eurasia ( Kalkan et all., 2008).

However, the inadequacy of regulation contents and performance analysis in this context has not prevented major earthquake damages, continued to cause loss of life and property. Turkey Building Earthquake Code - 2018 (TBEC 2018), which was formed as a result of performance analysis studies, came into force. In this context, performance analysis of an existing reinforced concrete shear wall structure within the borders of Istanbul province located in the dangerous earthquake zone was made according to TBEC-2018. Dya and Oretaa (2015) seismic vulnerability assessment of soft story irregular buildings using pushover analysis. Inel and Meral (2016) evaluated seismic performance of existing low and mid-rise reinforced concrete buildings by comparing their displacement capacities and displacement demands under selected ground motions experienced in Turkey. Jialiang and Wang (2017) the model with four-stories and two-bays was pseudo-dynamically tested under six earthquake actions whose peak ground accelerations (PGA) vary from 50 gal to 400 gal. Huang et all (2017) a linear analysis procedure was developed for accurate assessment of the seismic performance of buildings and the computation of direct and indirect economic losses resulting from earthquake shaking and is suitable for application to low- and medium-rise buildings of regular configuration.

The objective of this study is Perfomance based assessment of existing complex in plan shear-walled building with strengthbased method, one of the linear method, and displacementbased approach, one of the nonlinear method. Determining seismic performance of existing building is important because of getting ready for probable earthquake to be occured.

The building is typical beam-column RC frame buildings with shear walls. The selected building was designed according to TEC-1998 considering both gravity and seismic loads. The nonlinear dynamic analysis is performed by using the finite element program SAP 2000. Beam and column elements are modeled as nonlinear frame elements with lumped plasticity by defining plastic hinges at both ends of beams and columns. Seismic performance evaluation is carried out in accordance with the recently published TBEC-2018 that has similarities with FEMA-356 guidelines. This existing complex designed reinforced concrete building investigated in this study is in the city of İstanbul, Turkey. This city is under danger of approaching and inevitable Great Istanbul Earthquake likely greater than $\mathrm{Mw}$ 7. Thus, investigation of earthquake 
performances of this or similar complex buildings are very important.

\section{THEORY}

\subsection{General Principles for The Evaluation and Design of Buildings Under Earthquake Effects According to TBEC-2018}

As shown in Fig. 1a, five points labeled A, B, C, D, and E define force-deformation behavior of a plastic hinge. The values assigned to each of these points vary depending on type of element, material properties, longitudinal and transverse steel content, and axial load level on the element (ATC-40; FEMA-273, Çavdar et all.,2018).

Similar to ATC and FEMA, three limit conditions have been defined for ductile elements on the cross section in TBEC2018. These are Limited Damage Reigion (SH), Marked Damage (KH) and Collapsing Limit (GÖ) (Figure 1b).

Performance Levels of Buildings to be Designed Under the Effect of Earthquake according to TBEC-2018 (Figure 1b):

a) Limited Damage Performance Level (SH); the building corresponds to the level of damage to the structural system elements, whereby a limited degree of damage or non-linear behavior occurs.

b) Controlled Damage Performance level $(\mathrm{KH})$; in order to ensure life safety, the building seismic resisting system corresponds to the level of controlled damage which is not very heavy.

c) Collapse Prevention Performance Level (GÖ); the building corresponds to the to the pre-cash situation where severe damage to the structural system elements occurs. Partial or complete collapse of the building was prevented.

Turkish building earthquake code was also under the influence of two different design approaches and their corresponding calculation steps described.

\subsubsection{Strength-based Design Approach}

In the approach of Strength-Based Design, (a) reduced seismic loads is determined corresponding resisting system ductility capacity defined for a projected certain performance target (b) linear seismic calculation of resisting system is done under reduced seismic loads. Strength demands are obtained by combining reduced internal forces found from this calculation, if needed by taking into account the excessive strength, and the internal forces occurred from other loads. The Linear Earthquake Calculation (LEC) with Equivalent Seismic Load Method (ESLM) applicable buildings given in Table 1.

LEC with ESLM is done as follows:

LEC with ESLM is done as follows:

$$
\begin{aligned}
& V_{t E^{(X)}}=m_{t} S_{a R}\left(T_{p}^{(X)}\right) \geq 0.04 m_{t} I S_{D S} g \\
& V_{t E^{(Y)}}=m_{t} S_{a R}\left(T_{p}^{(Y)}\right) \geq 0.04 m_{t} I S_{D S} g
\end{aligned}
$$

$$
\begin{aligned}
& \Delta \mathrm{FN}=0.0075 \mathrm{~N} \mathrm{~V}_{\mathrm{TE}} \\
& F_{\mathrm{I} E}=(V T E-\Delta \mathrm{FN})-\frac{W_{\mathrm{I}} H_{\mathrm{I}}}{\sum_{J=1}^{N} W_{J} H_{J}}
\end{aligned}
$$

Additional equivalent seismic load, $\Delta_{\mathrm{FN}}$, acting at the N'th storey (top) of the building shall be determined by Equation (3). Excluding $\Delta_{\mathrm{FN}}$, remaining part of the total equivalent seismic load shall be distributed to stories of the building (including N'th storey) in accordance with Equation (4).

In the Equation 1-4, $\mathrm{V}_{\mathrm{tE}}$ is basement shear force, $\mathrm{m}_{\mathrm{t}}$ is total mass, $S_{\mathrm{aR}}$ is reduced design spectral acceleration, $\mathrm{I}$ is building importance factor, $S_{D S}$ is short period design spectral acceleration factor, the $T_{p}^{(X)}$ is the natural vibration period prevailing in the $\mathrm{X}$ direction of the building, $\mathrm{T}_{\mathrm{p}}{ }^{(\mathrm{Y})}$ is the natural vibration period prevailing in the $\mathrm{Y}$ direction of the building, $g$ is acceleration of gravity, $F_{i E}$ is $i$. equivalent earthquake load acting on the center of mass.

In the 15th part of the TBEC-2018, the calculation of the Equivalent Seismic Load Calculation shall be made taking into calculation the following situation:

The buildings in which the ESLMcan be applied are given in Table 4.4. According to TBEC-2018, additional eccentricity will not be taken into calculation in the earthquake calculation of buildings. In the calculation of the total equivalent earthquake load (base shear force) according to Eq. (1) and Eq. (2) $\mathrm{Ra}=1$ will be taken.

In addition, in order to perform the calculation of the the

\begin{tabular}{|c|c|c|}
\hline \multirow[b]{2}{*}{ Building Type } & \multicolumn{2}{|c|}{ Allowed Building Height Class } \\
\hline & $\mathrm{EDC}=1,1 \mathrm{a}, 2,2 \mathrm{a}$ & $\begin{array}{l}\mathrm{EDC}=3,3 \mathrm{a}, 4, \\
4 \mathrm{a}\end{array}$ \\
\hline $\begin{array}{l}\text { Buildings where the } \\
\text { torsional irregularity } \\
\text { coefficient of each layer } \\
\text { provides the condition } \\
\text { pbi } \leq 2.0 \text { and also the } \\
\text { type B2 of irregularity }\end{array}$ & $\mathrm{BHC} \geq 4$ & $\mathrm{BHC} \geq 5$ \\
\hline All Other Buildings & $\mathrm{BHC} \geq 5$ & $\mathrm{BHC} \geq 6$ \\
\hline
\end{tabular}
equivalent static method, existing structure seems to meet the following boundary conditions:

The building height class is smaller than 5 (BHC <5). 


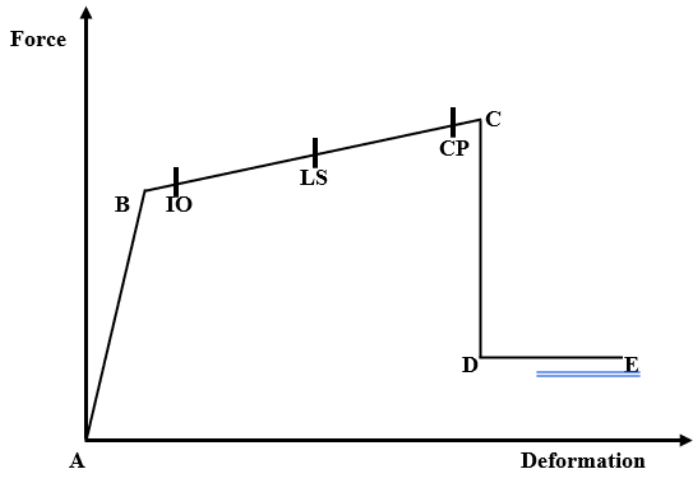

(a)

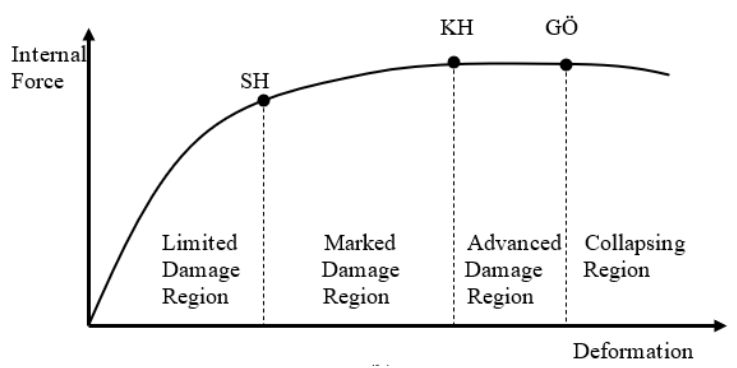

(b)

Figure 1. Building performance levels according to TBEC2018.

\subsubsection{Deformation-Based Design Approach}

The Deformation-Based Design Approach (DBDA) is a modern design approach that is expected to be used more widely in the near future, allowing the modeling of the actual behavior of the seismic resisting system for a variety of performance goals and its nonlinear calculation (TBEC-2018).

In the Deformation-Based Design Approach, it is needed following steps according to the regulation:

- The internal force-deformation relationships of existing or previously designed structural system elements compatible with non-linear modeling approaches are determined.

- Under the earthquake ground motion selected in accordance with the performance target compatible with the Regulation, dynamic incremental methods are calculated in the static or time history of the seismic resisting system, deformation demands related to nonlinear ductile behavior and resistance to brittle behavior are obtained.

- The resulting deformation and internal force demands are compared with the deformation and strength capacities defined in accordance with the performance target specified in the regulation.

- For existing buildings, the assessment is defined by showing that the deformation and strength demands are below or exceed the deformation and resistance capacities corresponding to them.

- For the existing buildings to be newly constructed or reinforced, if the deformation and strength demands are below the corresponding deformation and resistance capacities, the deformation-based design is completed. Otherwise, the sections of the element are changed, and the calculation is repeated, and the deformation-based design is completed. (TBEC- 2018).

Deformation-based Design and Evaluations are taken into consideration as follows:

- Single Mode Pushover Methods can be used for buildings that have a Building Height Class (BHC) $\geq 5$ and meet the conditions found in the regulation.

- Multi-Pushover Methods are available for all buildings with a $\mathrm{BHC} \geq 2$.

- The Nonlinear Time History Analysis Method can be used for the earthquake calculation of all buildings. This method is mandatory for high-rise buildings in Section 13 of TBEC-2018.

\section{METHODS}

\subsection{Description of Investigated Reinforced Concrete Shear Wall Structure}

The existing reinforced concrete framed building in Bahçelievler district of İstanbul consists of a basement floor, ground floor and 4 floors. The plan of the building is $19.04 \mathrm{~m}$ in X-direction and $8.81 \mathrm{~m}$ long in Y-direction. Each floor is in $2.80 \mathrm{~m}$ in height and it is totally $16.8 \mathrm{~m}$ in height. Seismic resisting system is frame-shear wall system. The concrete class is C30 and the reinforcement steel is S420. Typical geometry and reinforcing detail of column and beam crosssection areas are shown in Fig.2. In Fig. 2, the number before " $\varnothing$ " is the number of bars, and after " $\varnothing$ " is the diameter of bar in $\mathrm{mm}$. The beam sizes in the building are designed as $25 \times 50$ $\mathrm{cm}$ and there are different column dimensions. Column dimensions are given Figure 2. The column dimensions in a defined position in the plan are the same in the other stories of the building. It is seen that Figure 2, longitudinal rebars are $\varnothing 16$ for all columns. The longitudinal reinforcement ratio of these columns varies between $1.1 \%$ and $1.5 \%$. The dimensions of all the beams in the building are the same as $25 \times 50 \mathrm{~cm}$. Beam longitudinal rebars are $3 \emptyset 16$ on top and $3 \varnothing 16$ in bottom for the residential building. Transverse rebars are $\varnothing 8 / 15 \mathrm{~cm}$ for columns and beams. Flexural rigidity is calculated for each member. Beams and columns were modeled as frame elements which were connected to each other at the joints.

The thickness of the slabs is the same throughout all floors, including two thicknesses of 12 and $13 \mathrm{~cm}$. The basement floor of the building is designed as a shear-wall. This situation does not continue on the upper floors. ZC ground class is used in the district of Bahçelievler, Istanbul. A constant load of 1.5 $\mathrm{kN} / \mathrm{m} 2$ and $2 \mathrm{kN} / \mathrm{m} 2$ as a moving load, except for its dead weight (TS 498, TS 500), are assigned to the building. A typical floor plan is shown in Figure 3. Three-dimensional finite element model of the residential building was prepared in structural analysis program (SAP2000) shown in Figure 4.

The vertical loads consist of live and dead loads of slabs, wall loads on beams and dead loads of columns and beams. Predominant mode periods of the building in $\mathrm{X}$ and $\mathrm{Y}$ directions are 0.904 and $0.713 \mathrm{~s}$, respectively, based on cracked section properties. 


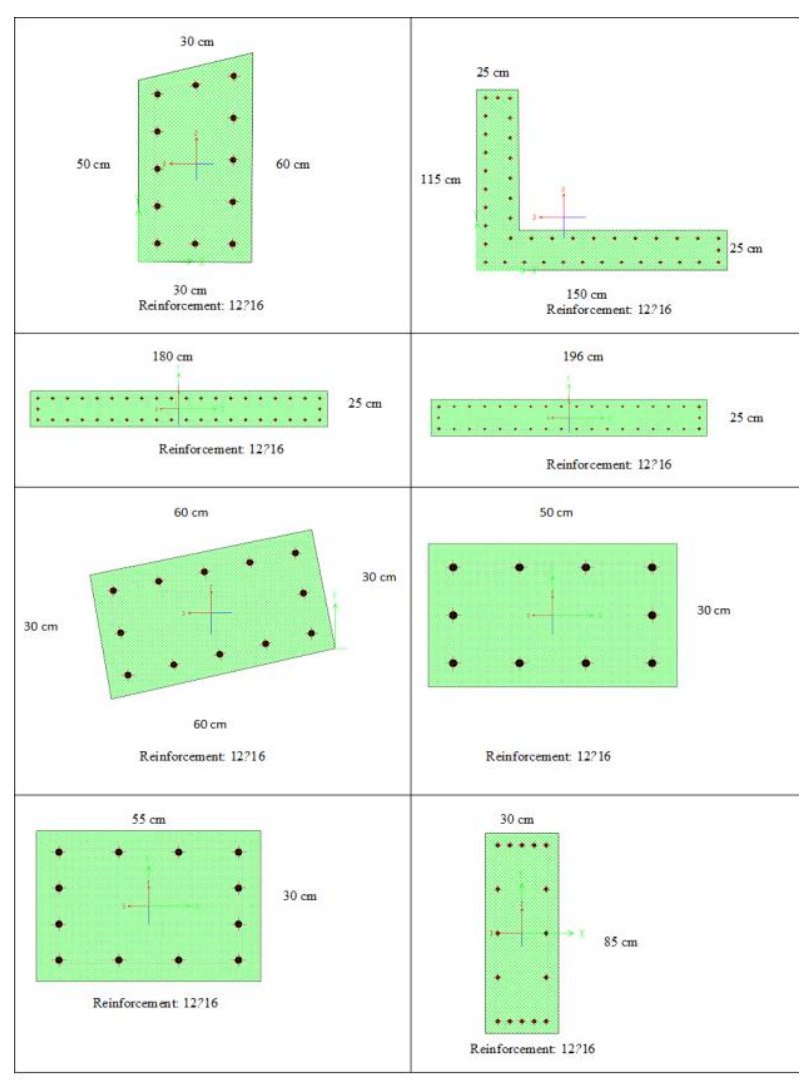

Figure 2. Dimensions and reinforcement of columns.

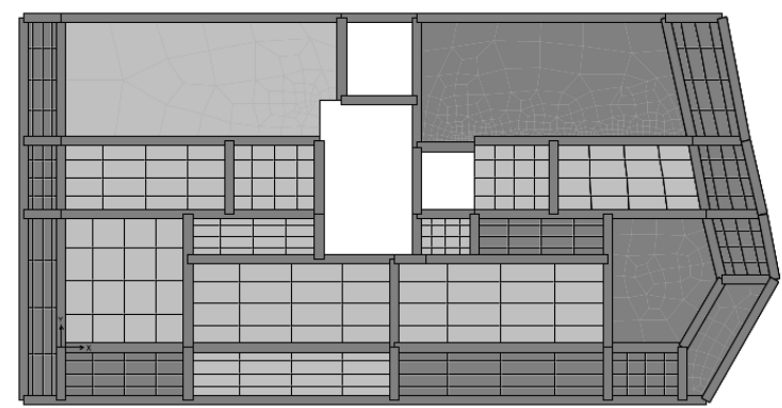

Figure 3. Typical floor plan of the building.

\subsection{Determination and Assignment of Earthquake Loads}

The floor weights required to calculate the earthquake loads shall be obtained from the sum of the mass values generated automatically by the program on the respective floor.

According to equivalent earthquake loads methods in TBEC2018, the horizontal earthquake loads, +0.05 and -0.05 eccentricities are not distributed to the floor levels without considering the existing structures.

The structure was modeled by SAP2000 program and all the required loading was applied on the model according to the information obtained from the regulations and the analysis result was examined. As a result of the analysis, it was observed that the first natural vibration period in the $\mathrm{X}$ direction of the structure $(\mathrm{T} 1 \mathrm{x})$ was $\mathrm{T}_{1 \mathrm{X}}=0.904 \mathrm{~s}$ and the first natural vibration period in Y-direction (T1y) was $0.713 \mathrm{~s}$. Natural vibration period; $\mathrm{T}_{\mathrm{pA}}=\mathrm{C}_{\mathrm{t}} \mathrm{HN}^{3 / 4}=0.1 \times(16.8)^{3 / 4}=$ $0.8298 \mathrm{~s}$ according to section 4.7.3 in TBEC-2018. According to this, the maximum natural value of the structure should not be taken more than 1.4 times of the $\mathrm{T}_{\mathrm{pA}}$ period $\left(\mathrm{T}_{\mathrm{pA}}=\right.$ $1.4 \times 0.8298=1.162 \mathrm{~s}$ ). Since the calculated dominant period values are smaller than this value, $\mathrm{T}_{1 \mathrm{X}}=0.904 \mathrm{~s}$ will be based on calculated. The building is located in the district of Kocasinan, Bahçelievler district of Istanbul. It has been found to be $41.0036^{\circ}$ North and longitude $28.8406^{\circ}$ East. Accordingly, Turkey Earthquake Hazard Map of the $S_{S}$ and $S_{1}$ values, respectively (AFAD,2018);

Map spectral acceleration coefficient for short period region $\mathrm{S}_{\mathrm{S}}=1.098 \mathrm{~g}$. The map spectral acceleration coefficient for the 1.0 second period region is $S_{1}=0.302 \mathrm{~g}$.

The local soil class at the location of the building is defined as ZC. According to this, local soil impact coefficients using the earthquake regulation $\mathrm{S}_{\mathrm{S}}=1.098$ and $\mathrm{S}_{1}=0.302\left(\mathrm{~F}_{\mathrm{S}}, \mathrm{F}_{1}\right)$ :

$\mathrm{F}_{\mathrm{S}}=1.2$ and $\mathrm{F}_{1}=1.5$

Design spectral acceleration coefficients:

$\mathrm{S}_{\mathrm{DS}}=\mathrm{S}_{\mathrm{S}} \mathrm{F}_{\mathrm{S}}=1.098 \times 1.2=1.318$
$\mathrm{~S}_{\mathrm{D} 1}=\mathrm{S}_{1} \mathrm{~F}_{1}=0.302 \times 1.5=0.453$

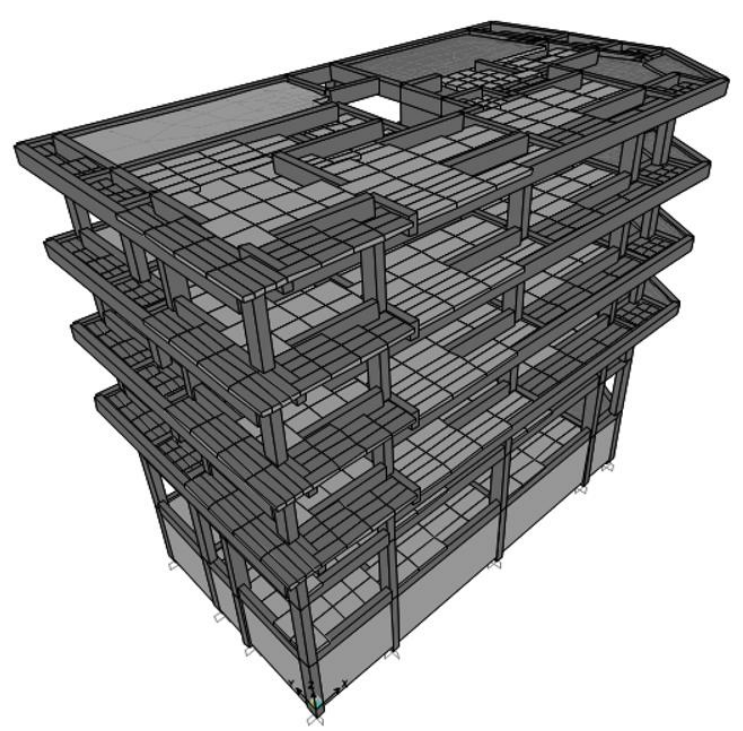

Figure 4. Three-dimensional finite element model of the residential building.

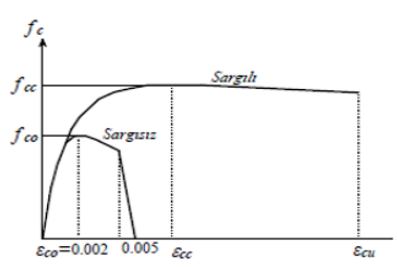

(a)

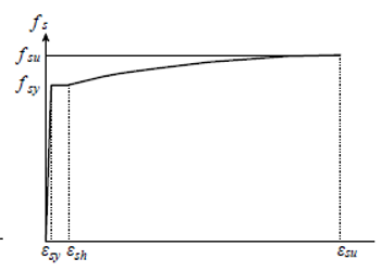

(b)
Figure 5. Stress-strain relationship of concrete (a) and reinforcing steel (b). 
As the structure is used as a conventional building, the building usage class $(\mathrm{BUC}=3$ ) and the Building Importance Factor I = 1.0 (TBEC-2018, Table 3.1). Earthquake Design Class $(\mathrm{EDC})$ is determined as $\mathrm{EDC}=1$ using $\mathrm{S}_{\mathrm{DS}}=1.318>$ 0.75 and $\mathrm{BUC}=3$ values (TBEC-2018 Table 3.2). Building Height Class is determined as $\mathrm{BHC}=6$ using $10.5 \mathrm{~m} \leq \mathrm{H}=$ $16.8 \mathrm{~m} \leq 17.5 \mathrm{~m}$ and Eathquake design class $($ EDC) $=1$ values (TBEC-2018 Table 3.3). Since the structure in question will be a cast-in-place (except for High-Rise Buildings) structures, for Earthquake Level DD-2 using the values of $\mathrm{BHC}=6 \geq 2$, DTS $=1$; Controlled Damage (CD) and design approach of the normal performance target were determined to be DBDA.

The remaining part of the total equivalent earthquake load $\Delta \mathrm{F}_{\mathrm{N}}$ is distributed to the building floors using the Equation 4. These values are given in the Table 2 .

Table 2. Total Equivalent Seismic Loads

\begin{tabular}{llllllll}
\hline Floor & hi $(\mathbf{m})$ & $\mathbf{H i}(\mathbf{m})$ & $\mathbf{W i}(\mathbf{k N})$ & $\mathbf{W i ~ H i}$ & Ratio & $\mathbf{F}_{\mathrm{ix}}(\mathbf{k N})$ & $\mathbf{F}_{\mathrm{iY}}(\mathbf{k N})$ \\
\hline 4 & 2.80 & 16.8 & 1607.057 & 26998.566 & 0.2005 & 1651.010 & 2088.600 \\
3 & 2.80 & 14 & 2684.503 & 37583.036 & 0.2791 & 1860.932 & 2360.062 \\
2 & 2.80 & 11.2 & 2684.503 & 30066.429 & 0.2233 & 1488.746 & 1888.050 \\
1 & 2.80 & 8.4 & 2684.503 & 22549.822 & 0.1672 & 1116.559 & 1416.037 \\
Ground & 2.80 & 5.6 & 1959.740 & 10974.543 & 0.0815 & 543.407 & 689.157 \\
floor & & & & & & & \\
Basement & 2.80 & 2.8 & 2315.058 & 6482.163 & 0.0481 & 180.023 & 180.023 \\
\hline Total: & & & 12971.44 & 134654.559 & & $6840.677\left(^{*}\right)$ & $8621.929\left(^{*}\right)$ \\
\hline
\end{tabular}

\section{RESULTS AND DISCUSSION}

\subsection{Calculation of Irregularity Types}

\subsubsection{A-1 Torsional Irregularity Calculation}

The calculation steps for A-1 torsional irregularity are shown in the following tables. According to this calculation, torsional irregularity coefficient $\mathrm{n}_{\mathrm{bi}}$ was greater than 1.2 was observed in the presence of torsional irregularity. The torsional irregularity ratio for each storey given in Table 3-4.

$\left(\Delta_{\mathbf{i}}\right)_{\text {ort }}=\frac{\left(\Delta_{\mathbf{i}}\right)_{\max }+\left(\Delta_{\mathbf{i}}\right)_{\min }}{2}$

$\eta_{b i}=\frac{\left(\Delta_{\mathbf{i}}\right)_{\max }}{\left(\Delta_{\mathbf{i}}\right)_{\text {ort }}}$

According to the data obtained from the calculations and the calculation steps taken from the above calculations (Equation 5) according to TBEC-2018. Torsional Irregularity was not found in the $\mathrm{X}$ and $\mathrm{Y}$ direction of the building.

Table 3. Calculating A-1 Torsional Irregularity in X Direction

\begin{tabular}{lllllll}
\hline Storey & dimin & $\operatorname{dimax}$ & $(\Delta \mathbf{i}) \mathbf{m i n}$ & $(\boldsymbol{\Delta} \mathbf{i}) \mathbf{m a x}$ & $(\boldsymbol{\Delta i})$ ort & pbi \\
\hline 4 & 0.2584 & 0.2958 & 0.0494 & 0.0481 & 0.0488 & 0.99 \\
3 & 0.209 & 0.2477 & 0.0571 & 0.0614 & 0.0592 & 1.04 \\
2 & 0.1519 & 0.1863 & 0.0617 & 0.0714 & 0.0666 & 1.07 \\
1 & 0.0902 & 0.1149 & 0.0564 & 0.0722 & 0.0643 & 1.12 \\
Ground & 0.0338 & 0.0427 & 0.0334 & 0.0423 & 0.0378 & 1.12 \\
floor & & & & & & \\
Basement & 0.0004 & 0.0004 & 0.0004 & 0.0004 & 0.0004 & 1 \\
\hline
\end{tabular}

Table 4. Calculating A-1 Torsional Irregularity in Y Direction

\begin{tabular}{lllllll}
\hline Storey & $\operatorname{dimin}$ & $\operatorname{dimax}$ & $\mathbf{( \Delta \mathbf { i } ) \mathbf { m i n }}$ & $\mathbf{( \Delta \mathbf { i } ) \mathbf { m a x }}$ & $(\boldsymbol{\Delta} \mathbf{i})$ ort & $\mathbf{n b i}$ \\
\hline 4 & 0.2584 & 0.2958 & 0.0494 & 0.0481 & 0.0488 & 0.99 \\
3 & 0.209 & 0.2477 & 0.0571 & 0.0614 & 0.0592 & 1.04 \\
2 & 0.1519 & 0.1863 & 0.0617 & 0.0714 & 0.0666 & 1.07 \\
1 & 0.0902 & 0.1149 & 0.0564 & 0.0722 & 0.0643 & 1.12 \\
Ground & 0.0338 & 0.0427 & 0.0334 & 0.0423 & 0.0378 & 1.12 \\
floor & & & & & & \\
Basement & 0.0004 & 0.0004 & 0.0004 & 0.0004 & 0.0004 & 1 \\
\hline
\end{tabular}

\subsubsection{B-2 Interstorey stiffness irregularity (Soft Storey)}

In the calculation of B-2 stiffness irregularity between interstorey stiffness, except basement floors, in the case of Stiffness Irregularity Coefficient $n_{k i}>2.0$ defined by the ratio of the mean relative floor displacement rate on any floor to the ratio of the average relative displacement in an upper or a lower floor, the Stiffness Irregularity check between the neighboring layers was performed.

$\eta_{k i}=\left(\Delta_{i} / h_{i}\right)_{\text {ort. }} . /\left(\Delta_{i+1} / h_{i+1}\right)_{\text {ort }}>2$

$\eta_{k i}=\left(\Delta_{i} / h_{i}\right)_{\text {ort. }} . /\left(\Delta_{i-1} / h_{i-1}\right)_{\text {ort } .}>2$

Table 5-6 shows the soft strorey irregularity calculations for $X$ and $\mathrm{Y}$ directions. In accordance with the above calculations, no calculation was found that the average relative floor displacement rates on one floor were greater than 2 . In other words, there is not type B-2 irregularity in the structure.

Table 5. B-2 calculation in $\mathrm{X}$ direction

\begin{tabular}{lcccccc}
\hline Storey & $\mathbf{h i}(\mathbf{m})$ & $\mathbf{d i}(\mathbf{m})$ & \multicolumn{1}{c}{$\mathbf{i}(\mathbf{m})$} & $(\mathbf{\Delta i} / \underline{\mathbf{h i}) \text { ort. }}$ & $\mathbf{r k i}\left(\mathbf{1 2}^{*}\right)$ & $\mathbf{\Gamma k i}\left(\mathbf{1 3}^{*}\right)$ \\
\hline 4 & 2.80 & 0.2785 & 0.0490 & 0.0175 & - & 0.83 \\
3 & 2.80 & 0.2295 & 0.0591 & 0.0211 & 1.21 & 0.88 \\
2 & 2.80 & 0.1704 & 0.0669 & 0.0239 & 1.13 & 1.04 \\
1 & 2.80 & 0.1035 & 0.0647 & 0.0231 & 0.97 & 1.69 \\
Ground & 2.80 & 0.0388 & 0.0384 & 0.0137 & 0.59 & - \\
floor & & & & & &
\end{tabular}

Table 6. B-2 calculation in $\mathrm{Y}$ direction

\begin{tabular}{|c|c|c|c|c|c|c|}
\hline Storey & hi (m) & di (m) & $\Delta \mathbf{i}(\mathbf{m})$ & $\begin{array}{ll}(\Delta \mathbf{i} & / \\
\text { hi)ort. }\end{array}$ & rki (12*) & rki $\left(13^{*}\right)$ \\
\hline 4 & 2.80 & 0.1140 & 0.0241 & 0.00368 & - & 0.77 \\
\hline 3 & 2.80 & 0.0899 & 0.0258 & 0.00479 & 1.30 & 0.83 \\
\hline 2 & 2.80 & 0.0641 & 0.0263 & 0.00575 & 1.20 & 0.99 \\
\hline 1 & 2.80 & 0.0378 & 0.0230 & 0.00579 & 1.01 & 1.49 \\
\hline $\begin{array}{l}\text { Ground } \\
\text { floor }\end{array}$ & 2.80 & 0.0148 & 0.0141 & 0.00389 & 0.67 & - \\
\hline
\end{tabular}

\subsection{Determination of Earthquake Performance Pushover Analysis Method}

The Pushover Analysis method based on the performances of the structures under different earthquakes in order to control and strengthen the seismic resisting systems of existing structures. The based performance value is determined by the degree of damage that may occur in the structural and nonstructural elements of the building. 
This method of analysis is much more complex than the forcebased calculations, however a more realistic method allows solutions to be more accurate and economical.

In this analysis method, the probability of exceeding the spectral magnitudes by 50 years was $2 \%$ and the corresponding repetition period was 475 years. In accordance with the information received from TBEC-2018, the status of Limited Damage (LD), Controlled Damage (CD), Precollapse Damage (PD) status of the existing structure were examined. In accordance with the information received from TBEC-2018.

It can be seen from the result under soil class $\mathrm{ZC}$ design earthquake of the pushover analysis through the $\mathrm{X}$ and $\mathrm{Y}$ direction (Figure 6) that building collapsed before reaching the push target. It is concluded from nonlinear static pushover analysis under design earthquake that according to displacement target of the building, the building not provided controlled damage performance level (CD) rating in the view of CD level targeted in TBEC-2018. According to TBEC2018, the reinforced concrete shear wall building is not expected to satisfy $\mathrm{CD}$ performance levels under design earthquake.

Design earthquake is converted to spectrum curve and modal displacement demand is determined and performance points are determined by TBEC-2018 as seen in Figure 7. The plastic hinges are obtained by pushing again the bearing system up to this demand. It is seen in Figure 7 that, in case the incremental repulsion analysis is conducted via applying the Incremental Equivalence Seismic Load Method, the "modal capacity

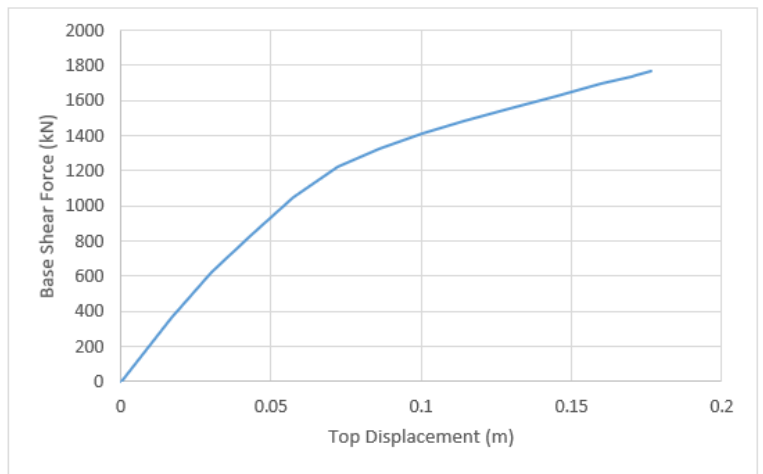

(a)

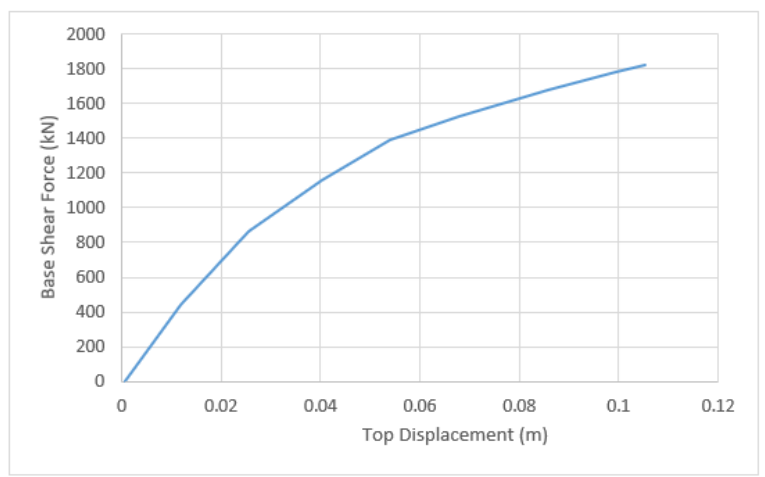

(b)

Figure 6. Capacity curves for $\mathrm{X}$ direction (a) and $\mathrm{Y}$ direction (b) by pushover analysis for 6-story buildings diagram" belonging to the primary (dominant) mode the coordinates of which are defined as "modal translocation modal acceleration" shall be derived. The modal translocation volition belonging to the primary (dominant) mode shall be set taking the elastic behaviors spectrum and the modifications applied on this spectrum for different exceeding probabilities together with the mentioned diagram into consideration. In the final step, the translocation, plastic deformation (plastic rotation) and inner force volitions that corresponds to the modal translocation volition shall be calculated.

As shown in Figure 6, with the effect of horizontal displacements of the existing building located within the boundaries of Istanbul, where the fault lines are of great

importance for the earthquake, the section damage of the sections with the result of the designation of hinges to the columns and beams according to the Pushover Analysis method regions are seen. After determination of damage regions of sections, the performance level of the building is controlled. It is seen from Figure 8 that the hinges through the $\mathrm{X}$ and $\mathrm{Y}$ directions of the structure after pushover analysis is under design earthquake (10\% in 50-year hazard level). In the $\mathrm{X}$-Direction of pushover analysis, no damage occurred in 182 $(79.82 \%)$ of the 228 columns areas in total, 39 (17.10\%) of them suffered minimal damage, and in 7 columns $(3.08 \%)$ collapse occurred. In addition, there were no damage on 397 beams $(68.92 \%)$ in 576 beam area, and minimum damage occurred on 179 beam $(31.08 \%)$.

In the Y-Direction of pushover analysis, no damage occurred in $177(77.63 \%)$ of 228 columns in total. 36 columns $(15.79 \%)$ are in minimally damaged columns region. significant damage is occurred in 7 columns $(3.07 \%)$, and in 8 columns (\% 3.51) collapse is occurred. In addition, there were no damage on 343 beams $(59.55 \%)$ and 576 beam girders, and 233 beams $(40.45 \%)$ are minimum damage zone. 


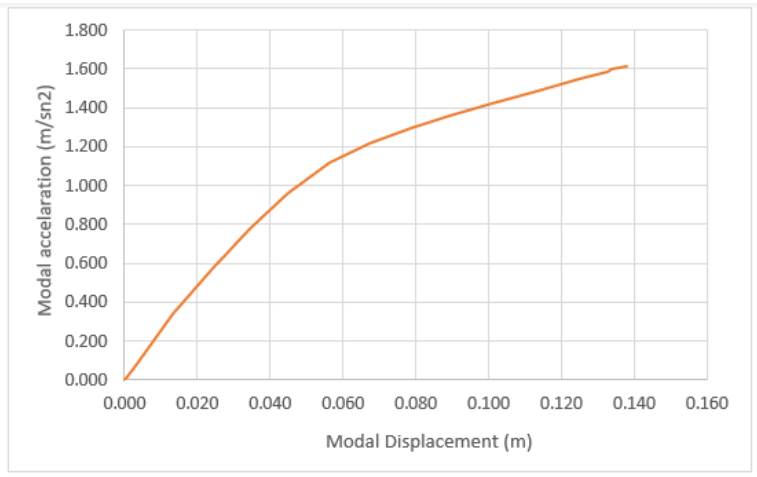

(a)

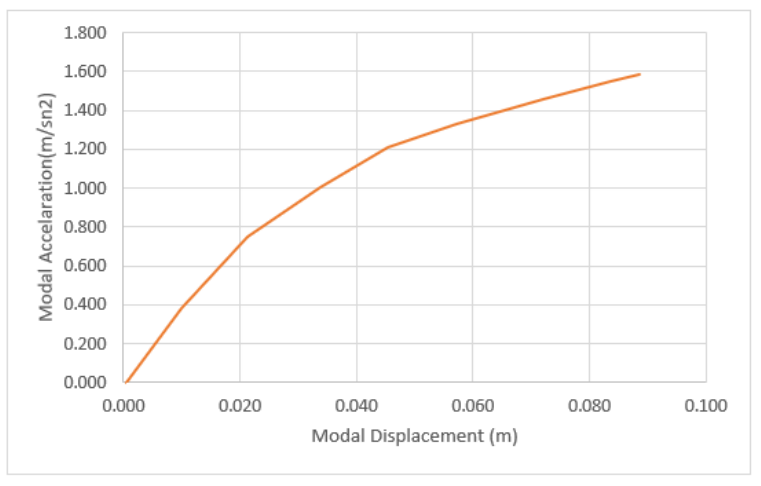

(b)

Figure 7. Modal Capacity curves for $\mathrm{X}$ direction (a) and $\mathrm{Y}$ direction (b) by pushover analysis for 6-story buildings.

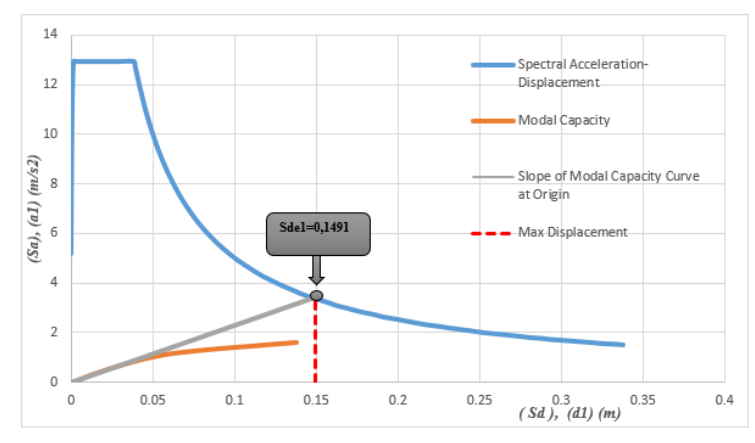

(a)

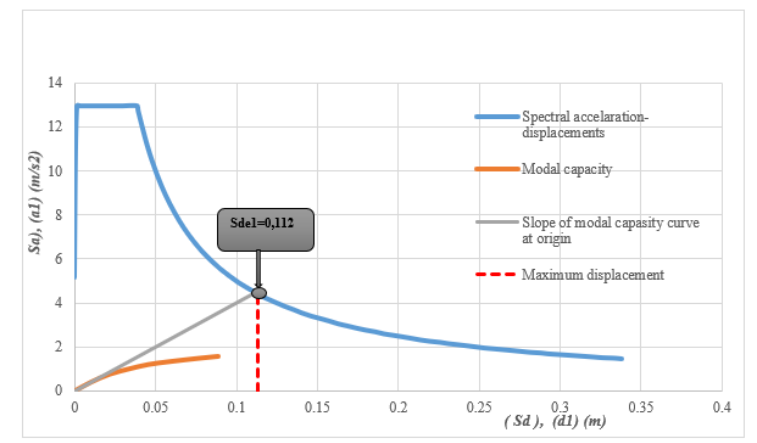

(b)

Figure 8. Spectral acceleration, spectral displacement, and modal capacity curves for $\mathrm{X}$ direction (a) and $\mathrm{Y}$ direction (b) by pushover analysis for 6-story buildings.

\section{CONCLUSIONS}

The purpose of performance-based earthquake engineering is to design and construct safe structures with seismic demands. The performance-based design method in earthquake engineering is used to determine the expected performance level under the effect of earthquake. For this purpose, different calculation methods have been developed and it is accepted by the scientific circles that the most reliable calculation methods are nonlinear calculation methods.

In this study, an existing building in Istanbul province is considered. One of the most important reasons for the selection of the existing structure in Istanbul is that the dangerous fault lines are present within the boundaries of this province. In line with this information, linear and nonlinear analysis of an existing structure according to TBEC-2018 was carried out. ESLM was used in linear analysis and pushover method was used nonlinear analysis method.

The determination of the building performance levels in the earthquake analysis is an important factor for the safe usability of the structures at the time of the earthquake. In the linear analysis, in accordance with the equivalent earthquake load, for the existing cast-in-place reinforced concrete (except for high buildings) $\mathrm{BHC}=6>2, \mathrm{EDC}=1$ using the class values of the normal performance target control for DD-2 Controlled Damage (CD). The design approach is determined as DBDA.

As a result of the analyzes, irregularity calculations were made according to the displacements in the $\mathrm{X}$ and $\mathrm{Y}$ direction:

In the analysis made according to $\mathrm{X}$ direction of the structure, only torsional irregularity is seen on the ground floor. In the $\mathrm{Y}$ direction, torsional irregularity is found on normal floors.

No discontinuity was found in the structure in any way to prevent the operation of the structural system element.

A-3 irregularity is observed in Y direction due to the fact that the right appearance of the structure does not provide a complete symmetry.

As a result of calculations in the $\mathrm{X}$ and Ydirections B-1 irregularity in the structure and as a result of the displacements as a result of the rigidity irregularity was not found.

As a result of the pushover analysis, it is seen that in the evaluation of X Direction line in ZC local floor class design earthquake, the Controlled Damage Performance Level which is the target performance for the buildings is provided. However, the same cannot be achieved for Y Direction. Because, since more than $35 \%(40.45 \%)$ of the beams were passed to the Advanced Damage Area according to the regulations of the existing building, the Controlled Damage Performance Level could not be achieved. In this respect, the building was evaluated according to the Level of Performance of Collapse Prevention. 


\section{REFERENCES}

[1] AFAD (2018). Disaster and Emergency Management Directorate. https://www.afad.gov.tr/ (Accessed on: 05.09.2020).

[2] ATC-40 (Applied Technology Council). (1996). "Seismic evaluation and retrofit of concrete buildings." 1(2), California.

[3] Celep, Z., (2018), Introduction to Earthquake Engineering and Earthquake Resistant Building Design, Istanbul.

[4] Çavdar, Ö., Çavdar, A., Bayraktar, E., (2018) Earthquake Performance of Reinforced-Concrete Shear-Wall Structure Using Nonlinear Methods. Journal of Performance of Constructed Facilities, 32(1):1-12, DOI: 10.1061/(ASCE) CF.1943-5509.0001117.

[5] Dya, A.F.C. and Oretaa, A.W. C. (2015) Seismic Vulnerability Assessment of Soft Story Irregular Buildings Using Pushover Analysis. Civil Engineering Innovation For A Sustainable Book Series: Procedia Engineering, $\quad$ 125: 925-932, DOI: 10.1016/j.proeng.2015.11.103

[6] FEMA-440 (Federal Emergency Management Agency). (2005). "Improvement of nonlinear static seismic analysis procedures." Washington (DC).

[7] Huang, Y.N, Whittaker, A.S. and Hamburger, R.O., (2017) A simplified analysis procedure for performancebased earthquake engineering of buildings. Engineering Structures, $\quad 150, \quad 719-735$, DOI: 10.1016/j.engstruct.2017.07.048
[8] Inel, M. and Meral, E., (2016). "Seismic performance of RC buildings subjected to past earthquakes in Turkey." Earthquakes and Structures, 11(3),483-503.

[9] Kalkan, E., Gülkan, N., Yılmaz Öztürk, N., and Çelebi, M., (2008) Seismic Hazard in the Istanbul Area: A Preliminary Re-Evaluation. Journal of Earthquake Engineering, 6(2): 1-13 DOI: $10.1080 / 13632460802013925$

[10] Jialiang, S. and Wang, Q.W., (2017) Seismic performance evaluation of RC frame-shear wall structures using nonlinear analysis methods, International Journal of Computational Materials Science and $\begin{array}{llll}\text { Engineering, } 6 & \text { (4): } \quad 88-97, \quad \text { DOI: }\end{array}$ $10.1142 / \mathrm{S} 2047684117500257$

[11] SAP2000 (Structural Analysis Program) (2015) Computers and Structures Inc. Berkeley, USA.

[12] TBEC-2018 (Turkey Building Earthquake Code) (2018) Specifications for buildings to be built in seismic areas. Ministry of Public Works and Settlement. Ankara, Turkey.

[13] Turkey Earthquake Hazard Map (TEHM) 2018. Turkey Earthquake Hazard Map AFAD-2018 is https://tdth.afad.gov.t (Access date: 08.03.2019)

[14] TS500, (2000) Calculations and Construction Rules of Reinforced Concrete Structures. Turkish Standards Institute, Ankara.

[15] TS498, (1987). Calculation Values of Loads to be Taken in Sizing of Building Elements, Turkish Standards Institute, Ankara. 